\title{
Improvement of a Critical Intermediate Step in the Synthesis of a Nitroxide-Based Spin-Labeled Deoxythymidine Analog
}

\author{
Jeannine H. Powell, Edward M. Johnson II and Peter M. Gannett* \\ Department of Basic Pharmaceutical Sciences, West Virginia University School of Pharmacy, \\ P. O. Box 9530, Morgantown, West Virginia, USA. Tel. (304)-293-1480, Fax (304) 293-2576. \\ *Author to whom correspondence should be addressed; e-mail pgannett@hsc.wvu.edu \\ Received: 8 May 2000; in revised form 13 November 2000 / Accepted: 14 November 2000 /
}

Published: 18 December 2000

\begin{abstract}
Methods to reduce the carboxylic acid moiety in 3-carboxy-2,2,5,5-tetramethylpyrrolin-1-oxyl to an alcohol as an intermediate toward the corresponding aldehyde have been explored and an improved method has been developed.
\end{abstract}

Keywords: Nitroxide, spin label, reduction, carboxylic acid, alcohol, anhydride

\section{Introduction}

Spin-labeled nucleic acids have been proposed as probes for the study of DNA conformation and dynamics $[\underline{1}, \underline{2}]$. A potentially very useful moiety is a thymidine analog coupled via an acetylene bridge to a pyrrolin-N-oxyl molecule [2]. The synthesis of this spin-labeled nucleic acid begins with stable nitroxides described by Rozantsev [3] ; further elaboration of these compounds is described in several sources $[2,4]$. In our hands, one of the most problematic steps in the overall synthesis is the reduction of the carboxylic acid moiety in $\mathbf{1}$ to the alcohol $\mathbf{2}$, which is then oxidized to the aldehyde $\mathbf{3}$, without perturbation of the nitroxide (Figure 1). Here we report several methods we have utilized for the conversion of 1 into 2 and in one instance of 1 into 3 . 


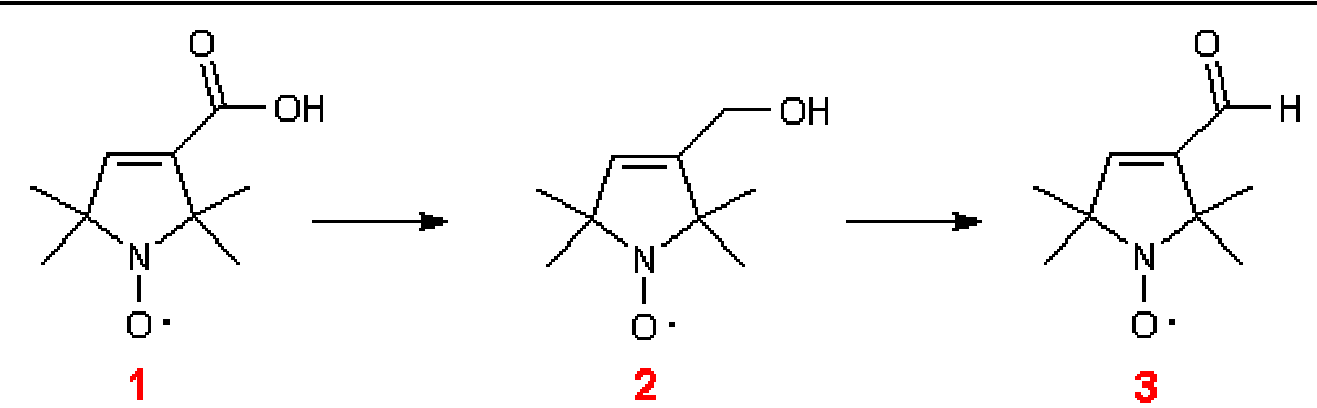

Figure 1

\section{Results and Discussion}

In 1989, Spaltenstein et al [2] reported synthesis of a spin-labeled thymidine analog phosphoramidite, from the aldehyde 3 (Figure 1). The synthesis of this aldehyde was described by Hideg et al [4], who prepared it by oxidation of the alcohol, 2. Compound 2 was prepared by reduction of 1 using sodium bis[2-methoxyethoxy]-aluminum hydride in $88 \%$ (Method 1). In our hands, we found this reduction difficult to control. In some cases the reaction appeared not to occur while at other times, the reaction occurred, but the reaction mixture became a gelatinous semi-solid from which it was difficult to isolate 2 . Therefore, we explored alternative reducing agents to affect the transformation of 1 to 2 or 3.

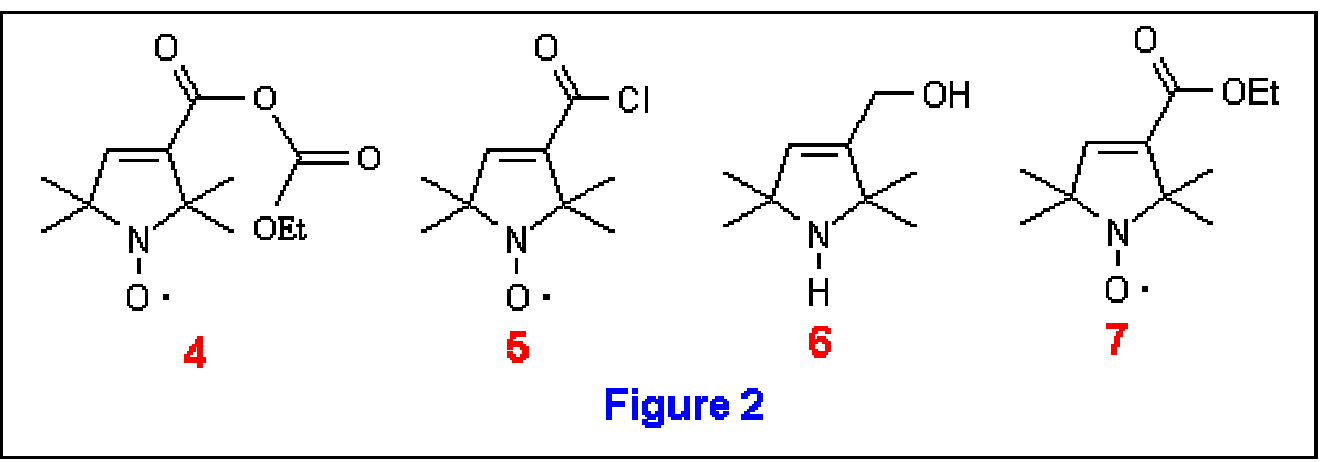

We first explored the reduction of the mixed anhydride 4. Griffith et al [5] had previously reported the preparation of the mixed anhydride 4 from 1 by treatment with ethyl chloroformate and triethylamine in ether [6]. After isolation of 4 it was reduced to 2 with sodium borohydride in ethanol. However, in our hands, this reduction was incomplete and was accompanied by partial hydrolysis of 4. Separation of the reaction mixture on silica gel gave the desired alcohol 2, acid 1, and the mixed anhydride 4. The yield of the alcohol was $18 \%$ (or $66 \%$ based on recovered 1 and 4, Method 2). However, by using the conditions described by Ishizumi et al [7], reduction of 1 to 2 via 4 was achieved in 55\% yield (Method 3). 
Next, we explored a different strategy. Instead of reducing 1 to 2 and then oxidizing 2 to 3 , we pursued an alternate route from 1 to 3 . This route involved reducing the acid chloride 5 to the corresponding aldehyde according to the method of Brown and Rao [] $]$ by treating 5 with lithium tri- $t$ butoxyaluminohydride in diglyme at $-78^{\circ} \mathrm{C}$ (Method 4). This reaction worked well but removal of the diglyme proved problematic due to the volatility of 3 . We found that this reaction could be conducted in THF with similar results and the product 3 was isolated in $60 \%$ yield.

Methods 2-4, however, did not give yields superior to those reported by Hideg and therefore, we returned to the original route of $1 \rightarrow 2 \rightarrow 3$. Rosen's work suggested that the nitroxide moiety was stable toward LAH reduction [9], in contrast with Rozantsev's assertion that LAH reduces nitroxides to hydroxylamines. We decided to explore this chemistry using LAH for the reduction of $\mathbf{1} \rightarrow \mathbf{2}$ and, after several attempts, found that by limiting the quantity of 1 to 2 grams or less, we could achieve $97 \%$ yields of 2 (Method 5). Occasionally, some over-reduction was observed yielding $\mathbf{6}$, in additon to the desired product 2 , especially if prolonged reaction times were used. However, 6 could be easily separated from the desired product by simple acid extraction.

Finally, since LAH reduces esters more readily than acids, we prepared the ethyl ester 7 by conversion of $\mathbf{1}$ to the acid chloride $\mathbf{5}$, followed by reaction with sodium ethoxide in ethanol to the ester 7. Reduction of 7 with LAH did reduce the ester to an alcohol, but the nitroxide was also reduced to an amine yielding 6 (Method 6).

Table 1. Comparison of Methods Used to Reduce Nitroxide 1.

\begin{tabular}{|c|c|c|c|}
\hline $\begin{array}{c}\text { Private } \\
\text { Method }\end{array}$ & Substrate & Conditions & Product (Yield) \\
\hline 1 & 1 & Sodium bis-(2-methoxyethoxy)-aluminum hydride/toluene/reflux & $2(88 \%)^{\mathrm{a}}$ \\
\hline 2 & 4 & $\mathrm{NaBH}_{4} /$ Ethanol & $2(66 \%)^{\mathrm{b}}$ \\
\hline 3 & 4 & $\mathrm{NaBH}_{4} / \mathrm{THF} /$ water & $2(55 \%)$ \\
\hline 4 & 5 & Lithium tri-tert-butoxyalumino-hydride/diglyme & $3(60 \%)$ \\
\hline 5 & 1 & LAH/THF/reflux/24h & $2(97 \%)^{\mathrm{c}}$ \\
\hline 6 & 7 & LAH/THF/reflux/2h & $6(17 \%)$ \\
\hline
\end{tabular}

${ }^{\mathrm{a}}$ Published yield [4].

${ }^{\mathrm{b}}$ Yield is based on recovered acid $\mathbf{1}$ and mixed anhydride 4

${ }^{\mathrm{c}}$ Yields based on $2 \mathrm{~g}$ or smaller scale.

\section{Conclusions}

We have presented a brief survey of various conditions which can be used for conversion of a carboxylic acid functional group of 1 to the corresponding alcohol 2 . The reduction of 1 to 2 is best achieved with LAH in THF, and as long as the scale of the reaction is 2 grams or less, yields of $97 \%$ can be realized. 


\section{Experimental}

\section{General}

The carboxylic acid 1 was prepared according to the method of Rozantsev [ 3 ] and purified by recrystallization from tetrahydrofuran (THF). All reagents were purchased from Aldrich Chemical Co. and solvents were purchased from Fisher Scientific. Purification of solvents was performed as follows: toluene and benzene were washed with concentrated sulfuric acid and distilled; ether and THF were distilled from lithium aluminum hydride; pyridine and triethylamine from calcium hydride; chloroform was distilled from phosphorus pentoxide. NMR spectra were measured on a Varian Gemini 300 broadband spectrometer. Analysis of purity for compounds 1, 2, and 3 was made by HPLC analysis (C$18(5 \mu \mathrm{m}, 2.6 \times 100 \mathrm{~mm})$, mobile phase $90 \%$ sodium acetate $(50 \mathrm{mM}, \mathrm{pH} 6), 10 \% \mathrm{MeOH}, \mathrm{UV}$ detection $(254 \mathrm{nM}$ ), flow rate $2.0 \mathrm{~mL} / \mathrm{min}$ (retention times: 1, $2.68 \mathrm{~min}, 2,3.60 \mathrm{~min}, 3,3.51 \mathrm{~min}$ ) and by comparison of their melting points to literature values.

Method 1 - The acid 1 (1.84 g, $10 \mathrm{mmol})$ was suspended in dry toluene $(10 \mathrm{~mL})$, to which $11 \mathrm{~mL}$ of a $70 \%$ solution of sodium bis[2-methoxyethoxy]-aluminum hydride was added dropwise. The solution was heated at reflux for two hours and quenched by addition to $100 \mathrm{~mL}$ of a $5 \%$ solution of sodium hydroxide. The organic phase was separated and dried over anhydrous sodium sulfate and the toluene removed in vacuo to yield $1.6 \mathrm{~g}(88 \%) 2\left(\mathrm{mp} 75-76^{\circ} \mathrm{C}\right.$; lit. $\left.75-77^{\circ} \mathrm{C}[4]\right)$

Method 2 - The acid 1 (1.2 g, $6.5 \mathrm{mmol})$ and triethylamine $(0.69 \mathrm{~g}, 6.8 \mathrm{mmol})$ were dissolved in ether $(50 \mathrm{~mL})$ and cooled in an ice-salt bath. Ethyl chloroformate $(0.71 \mathrm{~g}, 6.5 \mathrm{mmol})$ was added and the reaction was stirred for $1.5 \mathrm{~h}$. The reaction mixture was filtered to remove triethylamine hydrochloride, the ether filtrate was washed with cold $\mathrm{HCl}(5 \%, 10 \mathrm{~mL})$, water $(10 \mathrm{~mL})$, saturated $\mathrm{NaHCO}_{3}(10 \mathrm{~mL})$, and brine $(10 \mathrm{~mL})$. The ether layer was dried over $\mathrm{Na}_{2} \mathrm{SO}_{4}$, filtered and concentrated in vacuo to yield 4, $1.04 \mathrm{~g}(63 \%)$. This product was suspended in ethanol $(16.8 \mathrm{~mL})$, to which was added $\mathrm{NaBH}_{4}(560$ $\mathrm{mg}, 14.8 \mathrm{mmol}$ ) in two equal portions. The reaction was stirred for 30 minutes, the ethanol removed in vacuo, the product dissolved in water $(8 \mathrm{~mL})$, and extracted with chloroform (3 X $25 \mathrm{~mL})$. The organic layer was washed with saturated $\mathrm{NaHCO}_{3}(10 \mathrm{~mL})$ and water $(10 \mathrm{~mL})$, dried over $\mathrm{Na}_{2} \mathrm{SO}_{4}$, and concentrated in vacuo. Separation on silica gel (1:1 ethyl acetate/hexanes) afforded three fractions corresponding to compounds $\mathbf{1}, 4$ and 2 in a ratio of 1:3:1. After separation the yield of 2 (mp 75$76^{\circ} \mathrm{C}$; lit. $\left.75-77^{\circ} \mathrm{C}[4]\right)$ was $0.22 \mathrm{~g} \mathrm{(18 \% ,} \mathrm{based} \mathrm{on} 1,66 \%$ based on recovered 1 and 2).

Method 3 - The acid 1 (4.2 g, $23 \mathrm{mmol})$ and triethylamine $(2.36 \mathrm{~g}, 23 \mathrm{mmol})$ were dissolved in THF $(40 \mathrm{~mL})$. With cooling (ice-salt bath), ethylchloroformate $(2.95 \mathrm{~g}, 27 \mathrm{mmol})$ in THF $(7 \mathrm{~mL})$ was slowly added and the mixture stirred for 30 minutes. The triethylammonium chloride salts were filtered off and washed with THF (10 mL). The filtrate and washings were added dropwise to $\mathrm{NaBH}_{4}(2.36 \mathrm{~g}, 62$ mmol) in water $(30 \mathrm{~mL})$. This reaction was allowed to stir overnight. The mixture was acidified with 
$10 \% \mathrm{HCl}$ to destroy excess $\mathrm{NaBH}_{4}$ and then the solution was saturated with solid $\mathrm{NaCl}$, causing the separation of the THF and aqueous layers. The THF layer was removed, and the aqueous layer extracted repeatedly with methylene chloride $(15 \mathrm{~mL}$ aliquots) until no more yellow color was extracted into the organic phase. The $\mathrm{THF} /$ methylene chloride extract was dried over $\mathrm{MgSO}_{4}$ and concentrated to dryness in vacuo to give compound 2, yield $2.13 \mathrm{~g}(55 \%)\left(\mathrm{mp} 75-76^{\circ} \mathrm{C}\right.$; lit. $\left.75-77^{\circ} \mathrm{C}[4]\right)$.

Method 4 - The acid 1 (1.84 g, $10 \mathrm{mmol})$ was suspended in dry benzene ( $25 \mathrm{~mL})$ and cooled to 0$5^{\circ} \mathrm{C}$. Dry pyridine $(1 \mathrm{~mL})$ and then thionyl chloride $(0.9 \mathrm{~mL})$ were added dropwise. The reaction was stirred at room temperature for $30 \mathrm{~min}$ and then concentrated in vacuo. The residue (acid chloride 5) was dissolved in THF $(10 \mathrm{~mL})$, the flask flushed with nitrogen, cooled to $-78^{\circ} \mathrm{C}$, and maintained at that temperature as lithium tri-tert-butoxyaluminohydride $(2.1 \mathrm{eq}, 1 \mathrm{eq}$ to neutralize the pyridine hydrochloride) was added dropwise. The reaction was stirred at room temp for one hour. The mixture was quenched by the addition of $\mathrm{NH}_{4} \mathrm{Cl}(10 \%, 10 \mathrm{~mL})$, the layers separated and the aqueous layer extracted with $\mathrm{CH}_{2} \mathrm{Cl}_{2}(10 \mathrm{~mL})$. The combined organic layers were dried, filtered and concentrated to yield the crude aldehyde 3 . The product 3 was purified by chromatography (silica gel, 3:1 hexane/ethyl acetate). Compound 3 yield: $1.01 \mathrm{~g}(60 \%)\left(\mathrm{mp} 77-79^{\circ} \mathrm{C}\right.$; lit. $\left.78-79^{\circ} \mathrm{C}[\underline{4}]\right)$

Method 5 - To a solution of $\mathbf{1}(1.84 \mathrm{~g}, 10 \mathrm{mmol})$ in dry THF $(10 \mathrm{~mL})$ was added, dropwise, a solution of LAH in THF (1.0 M, $10 \mathrm{~mL})$, and the mixture stirred at room temp for 12 hours. The reaction was quenched by the addition of water $(0.4 \mathrm{~mL}), 15 \%$ sodium hydroxide $(0.4 \mathrm{~mL})$ and water $(1.2 \mathrm{~mL})$, filtered, and concentrated in vacuo to yield $1.65 \mathrm{~g}$ of $2(97 \%)\left(\mathrm{mp} 75-76^{\circ} \mathrm{C}\right.$; lit. $\left.75-77^{\circ} \mathrm{C}[4]\right)$. Scale-up proved problematic as the same procedure when repeated using $2 \mathrm{~g}$ or $4 \mathrm{~g}$ of 1 resulted in declining yields of $76 \%$ and $41 \%$, respectively. In the latter case the product was a mixture of the nitroxide 2 and a compound whose ${ }^{1} \mathrm{H}-\mathrm{NMR}$ was consistent with the corresponding amine 6.

Method 6 - The acid chloride 5 was prepared as described under Method 4 and then the solvents removed in vacuo. A solution of sodium ethoxide prepared from $0.25 \mathrm{~g}$ of sodium metal and absolute ethanol $(8 \mathrm{~mL})$ was added. The resulting mixture was heated at reflux for $2 \mathrm{hr}$, cooled to room temp and the salts removed by filtration. The filtrate was concentrated to dryness, dissolved in $\mathrm{CH}_{2} \mathrm{Cl}_{2}$ (50 $\mathrm{mL}$ ), washed with $5 \%$ aq $\mathrm{HCl}, 5 \%$ aq $\mathrm{NaOH}$, and $5 \% \mathrm{NH}_{4} \mathrm{Cl}\left(10 \mathrm{~mL}\right.$ each), dried $\left(\mathrm{MgSO}_{4}\right)$, filtered and concentrated to dryness to yield $7(1.2 \mathrm{~g}, 70 \%)\left(\mathrm{mp} 109-111^{\circ} \mathrm{C}\right.$; lit [3] $\left.109.5-111^{\circ} \mathrm{C}\right)$. The crude product was dissolved in dry THF $(7 \mathrm{~mL})$ and added to LAH $(1 \mathrm{M}, 7 \mathrm{~mL})$. The mixture was stirred at $\mathrm{rm}$ temp for $2 \mathrm{~h}$ and then quenched by the addition of water $(0.3 \mathrm{~mL}), 15 \%$ aq $\mathrm{NaOH}(0.3 \mathrm{~mL})$ and water $(0.9 \mathrm{~mL})$. The reaction mixture was then filtered and concentrated in vacuo. The residue was dissolved in $\mathrm{CH}_{2} \mathrm{Cl}_{2}(50 \mathrm{~mL})$, washed with sodium hydroxide $(5 \%, 2 \times 10 \mathrm{~mL})$ hydrochloric acid $(5 \%, 2$ $\mathrm{x} 10 \mathrm{~mL})$, dried $\left(\mathrm{MgSO}_{4}\right)$, filtered and concentrated in vacuo. The hydrochloric acid extract was made basic by the addition of aqueous $10 \%$ sodium hydroxide, extracted with $\mathrm{CH}_{2} \mathrm{Cl}_{2}(3 \times 20 \mathrm{~mL})$, dried $\left(\mathrm{MgSO}_{4}\right.$ ), filtered and concentrated in vacuo. The latter extract contained the product 6 (Yield: $0.27 \mathrm{~g}$, $17 \%)$. 
NMR data - [Note: all nitroxides were reduced to hydroxylamines for NMR analysis with 1.1 equivalents $\mathrm{Na}_{2} \mathrm{~S}_{2} \mathrm{O}_{4}$ in a 1:1 mixture of $\mathrm{D}_{2} \mathrm{O}: \mathrm{d}_{6}$-acetone.]

Carboxylic acid 1: ${ }^{1} \mathrm{H}-\mathrm{NMR}\left(1: 1 d_{6}\right.$-acetone, $\left.\mathrm{D}_{2} \mathrm{O}\right) \delta \mathrm{ppm} 1.57\left(\mathrm{~s}, 6 \mathrm{H}, 2-\mathrm{CH}_{3}\right), 1.67(\mathrm{~s}, 6 \mathrm{H}, 2$ $\left.\mathrm{CH}_{3}\right), 6.52(\mathrm{~s}, 1 \mathrm{H},=\mathrm{CH}-) ;{ }^{13} \mathrm{C}-\mathrm{NMR}\left(1: 1 d_{6}\right.$-acetone, $\left.\mathrm{D}_{2} \mathrm{O}\right) \delta 27.17\left(2 \mathrm{C}, 2-\mathrm{CH}_{3}\right), 27.35\left(2 \mathrm{C}, 2-\mathrm{CH}_{3}\right)$, 68.36 (1 C, quaternary), 70.87 (1C, quaternary), $137.0\left(=\underline{\mathrm{C}}-\mathrm{CO}_{2} \mathrm{H}\right), 148.8(=\mathrm{CH}-), 167.4\left(=\mathrm{C}-\underline{\mathrm{CO}_{2} \mathrm{H}}\right)$.

Alcohol 2: ${ }^{1} \mathrm{H}-\mathrm{NMR}\left(1: 1 d_{6}\right.$-acetone, $\left.\mathrm{D}_{2} \mathrm{O}\right) \delta \mathrm{ppm} 1.45\left(\mathrm{~s}, 6 \mathrm{H}, 2-\mathrm{CH}_{3}\right), 1.47\left(\mathrm{~s}, 6 \mathrm{H}, 2-\mathrm{CH}_{3}\right), 4.31$ $\left(\mathrm{s}, 1 \mathrm{H},-\mathrm{CH}_{2^{-}}\right), 4.32\left(\mathrm{~s}, 1 \mathrm{H},-\mathrm{CH}_{2^{-}}\right), 5.81(\mathrm{~s}, 1 \mathrm{H},=\mathrm{CH}-) ;{ }^{13} \mathrm{C}-\mathrm{NMR}\left(1: 1 d_{6^{-}}\right.$-acetone, $\left.\mathrm{D}_{2} \mathrm{O}\right) \delta 23.84(2 \mathrm{C}$, $\left.2-\mathrm{CH}_{3}\right), 24.80\left(2 \mathrm{C}, 2-\mathrm{CH}_{3}\right), 58.21\left(1 \mathrm{H},-\mathrm{CH}_{2}-\mathrm{OH}\right), 70.13$ (1 C, quaternary), 72.20 (1C, quaternary), $128.5\left(=\mathrm{C}-\mathrm{CH}_{2} \mathrm{OH}\right), 144.5$ (=CH-).

Aldehyde 3: ${ }^{1} \mathrm{H}-\mathrm{NMR}\left(1: 1 d_{6}\right.$-acetone, $\left.\mathrm{D}_{2} \mathrm{O}\right) \delta \mathrm{ppm} 1.44\left(\mathrm{~s}, 12 \mathrm{H}, 4-\mathrm{CH}_{3}\right), 7.11(\mathrm{~s}, 1 \mathrm{H},=\mathrm{CH}-), 9.69$ (-CHO); ${ }^{13} \mathrm{C}$-NMR $\left(1: 1 d_{6}\right.$-acetone, $\left.\mathrm{D}_{2} \mathrm{O}\right) \delta \mathrm{ppm} 24.37\left(2 \mathrm{C}, 2-\mathrm{CH}_{3}\right), 24.52\left(2 \mathrm{C}, 2-\mathrm{CH}_{3}\right), 68.47(1 \mathrm{C}$, quaternary), 68.58 (1C, quaternary), 146.31 (=C-CHO), 156.66 (=CH-), 191.02 (-CHO).

Mixed anhydride 4: ${ }^{1} \mathrm{H}-\mathrm{NMR}\left(1: 1 d_{6}\right.$-acetone, $\left.\mathrm{D}_{2} \mathrm{O}\right) \delta \mathrm{ppm} 1.473\left(\mathrm{~s}, 6 \mathrm{H}, 2-\mathrm{CH}_{3}\right), 1.51(\mathrm{t}, 3 \mathrm{H}$, $\mathrm{CH}_{2} \underline{\mathrm{C}}_{3}, \mathrm{~J}=7.1 \mathrm{~Hz}$ ), 1.55 (s, $\left.6 \mathrm{H}, 2-\mathrm{CH}_{3}\right), 4.42$ (q, $\left.2 \mathrm{H},-\mathrm{OC}_{2} \mathrm{CH}_{3}, \mathrm{~J}=7.1 \mathrm{~Hz}\right), 6.92(1 \mathrm{H},=\mathrm{CH}-)$.

Ester 7: ${ }^{1} \mathrm{H}-\mathrm{NMR}\left(1: 1 d_{6}\right.$-acetone, $\left.\mathrm{D}_{2} \mathrm{O}\right) \delta \mathrm{ppm} 1.47\left(\mathrm{~s}, 6 \mathrm{H}, 2-\mathrm{CH}_{3}\right), 1.50(\mathrm{t}, 3 \mathrm{H}, \mathrm{J}=7.1 \mathrm{~Hz}$, $\mathrm{C}_{3} \mathrm{CH}_{2} \mathrm{O}$ ), 1.54 (s, 6H, 2- $\left.\mathrm{CH}_{3}\right), 4.41$ (q, 2H, J=7.1 Hz, $\left.\mathrm{CH}_{3} \mathrm{C}_{2} \mathrm{O}\right), 6.91(\mathrm{~s}, 1 \mathrm{H}, \mathrm{CH}) ;{ }^{13} \mathrm{C}-\mathrm{NMR}(1: 1$ $d_{6}$-acetone, $\left.\mathrm{D}_{2} \mathrm{O}\right) \delta \mathrm{ppm} 13.68\left(\mathrm{CH}_{3} \mathrm{CH}_{2} \mathrm{O}\right), 24.32\left(2 \mathrm{C}, 2-\mathrm{CH}_{3}\right), 24.41\left(2 \mathrm{C}, 2-\mathrm{CH}_{3}\right), 60.98$ $\left(\mathrm{CH}_{3} \underline{\mathrm{CH}}_{2} \mathrm{O}\right), 68.05$ (1 C, quaternary), 69.72 (1 C, quaternary), 136.7 (=드- $\left.\mathrm{CO}_{2}\right), 146.6(=\mathrm{CH}-), 164.8$ (COOEt).

\section{References}

1. Strobel, O. K.; Kryak, D. D.; Bobst, E. V.; Bobst, A. M. Preparation and Characterization of SpinLabeled Oligonucleotides for DNA Hybridization. Biocon. Chem. 1991, 289-95.

2. Spaltenstein, A.; Robinson, B. H.; Hopkins, P. B. Sequence- and Structure-Dependent DNA Base Dynamics: Synthesis, Structure and Dynamics of Site and Sequence Specifically Spin- Labeled DNA. Biochemistry 1989, 28, 9484-9495.

3. Rozantsev, E. G. Synthesis of Some Stable Radicals and the Most Important Intermediates. In: Free Nitroxyl Radicals ; Plenum Press:New York, 1970; pp 203-246.

4. Hideg, K.; Hankovszky, H. O.; Lex, L.; Kulcsar, G. Nitroxyls VI. Synthesis and Reactions of 3Hydroxymethyl-2,2,5,5-tetramethyl-2,5-dihydropyrrole-1-oxyl and 3-Formyl Derivatives. Synthesis 1980, 911-914.

5. Griffith, O. H.; Keana, J. F. W.; Noall, D. L.; Ivey, J. L. Nitroxide Mixed Carboxylic-carbonic Acid Anhydrides. A New Class of Versatile Spin Labels. Biochim. Biophys. Acta 1963, 14, 8583-8585.

6. Keana, J. F. W. Newer Aspects of the Synthesis and Chemistry of Nitroxide Spin Labels. Chem. Rev. 1978, 78, 37-4. 
7. Ishizumi, K.; Koga, K.; Yamada, S.-I. Chemistry of Sodium Borohydride and Diborane. IV. Reduction of Carboxylic Acids to Alcohols with Sodium Borohydride through Mixed CarbonicCarboxylic Acid Anhydrides.Chem. Pharmaceut, Bull. (Japan) 1968, 16, 492-497.

8. Brown, H. C.; Rao, B. C. S. A New Aldehyde Synthesis - the Reduction of Acid Chlorides by Lithium Tri-t-butoxyaluminohydride. J. Amer. Chem. Soc. 1958, 80, 5377-5380.

9. Rauckman, E. J.; Rosen, G. M. Synthesis of Spin Labeled Probes: Esterification and Reduction. Syn. Commun. 1976, 6, 325-329.

Sample Availability: Samples are available from the authors (or from MDPI)

(C) 2000 by MDPI (http://www.mdpi.org) 